\title{
COMPETITION LAW ISSUES IN THE UPSTREAM OIL AND GAS INDUSTRY
}

\section{HARRY CHANDLER*}

The Competition Act has many implications for Canada's oil and gas industry. To assist the industry in understanding the application of the Act, the author reviews the treatment of horizontal agreements in restraint of trade and describes some of their statutory and jurisprudential defences. The enforcement agency's Program of Compliance and current law enforcement policies are also detailed.

\section{TABLE OF CONTENTS}

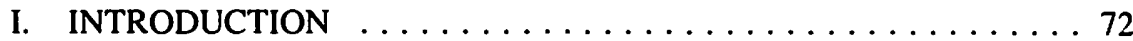

II. COMPLIANCE AND CRIMINAL

LAW ENFORCEMENT $\ldots \ldots \ldots \ldots \ldots \ldots \ldots \ldots \ldots$

A. CORPORATE COMPLIANCE $\ldots \ldots \ldots \ldots \ldots \ldots \ldots 73$

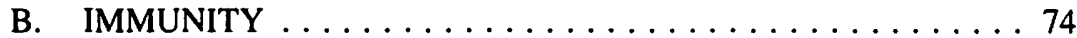

C. ADVISORY OPINIONS $\ldots \ldots \ldots \ldots \ldots \ldots \ldots \ldots \ldots$

D. PRIVATE ACTION $\ldots \ldots \ldots \ldots \ldots \ldots \ldots \ldots \ldots$

III. CRIMINAL OFFENCES -

HORIZONTAL AGREEMENTS $\ldots \ldots \ldots \ldots \ldots \ldots \ldots \ldots 75$

A. SECTION $45-$ CONSPIRACY $\ldots \ldots \ldots \ldots \ldots \ldots$

B. SECTION 47 - BID-RIGGING $\ldots \ldots \ldots \ldots \ldots \ldots \ldots 77$

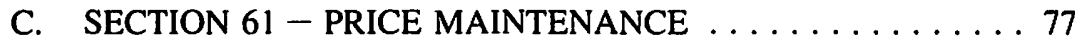

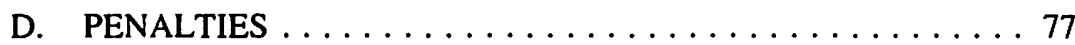

IV. GUIDANCE ON OIL AND GAS ISSUES $\ldots \ldots \ldots \ldots \ldots \ldots 78$

A. STATUTORY DEFENCES AND EXCEPTIONS $\ldots \ldots \ldots \ldots 78$

B. NATURAL GAS PRICING ISSUES $\ldots \ldots \ldots \ldots \ldots \ldots$

C. ALBERTA'S NATURAL GAS

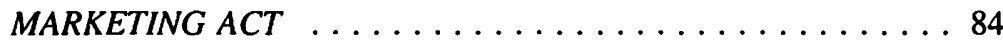

v. CONCLUSION $\ldots \ldots \ldots \ldots \ldots \ldots \ldots \ldots \ldots \ldots \ldots$

\section{INTRODUCTION}

With the removal of many aspects of economic regulation of Canada's oil and gas industry in the last few years, it has become increasingly important to understand the Competition Act and its effect upon the industry.'

Understandably there is great interest in the criminal law provisions of the Act and the manner in which they are currently enforced. This paper discusses a number of the

Deputy Director of Investigation and Research, Criminal Matters, Bureau of Competition Policy. This paper was largely prepared by Thomas Steen and Charles Schwartzman of the Bureau of Competition Policy.

Combines Investigation Act, R.S.C. 1985, c. C-34, as am. Competition Act, R.S.C. 1985 (2d Supp.), c. 19 , ss. 18-128. 
competition law issues in the upstream oil and gas industry in the context of the principal criminal law provisions of the Competition Act.

The Competition Act replaced the Combines Investigation Act and came into force in 1986. The new Act was required to enable Canada's competition laws to be more effective and to bring the Act into line with the Charter of Rights and Freedoms. The Act is designed to remove obstacles to free and open competition and to promote efficiency nationally, and to expand opportunities for Canadian business internationally. ${ }^{2}$

\section{COMPLIANCE AND CRIMINAL LAW ENFORCEMENT}

The Director of Investigation and Research ("the Director") has the responsibility of administering and enforcing the Competition Act. The Director is the head of the Bureau of Competition Policy ("the Bureau") which is a part of the federal Department of Consumer and Corporate Affairs.

The Act empowers the Director to conduct an inquiry whenever he believes, on reasonable grounds, that an offence under the Act has been or is about to be committed, or that grounds exist for the making of an order by the Competition Tribunal. ${ }^{3}$ All inquiries are conducted in private. ${ }^{4}$ Once an inquiry begins, the Director has several investigative tools including the use of search warrants at his disposal. ${ }^{5}$

While the Director investigates anti-competitive activity, the Attorney General of Canada ("the Attorney General") prosecutes violators of the criminal provisions of the Act. Both corporations and individuals can be charged. Penalties include fines, imprisonment or both. The Attorney General can also apply to the court for a Prohibition Order and interim injunctions.

\section{A. CORPORATE COMPLIANCE}

The Director's Program of Compliance is designed to provide business with greater awareness and understanding of the application of the Competition Act. The Director

The Act contains both criminal law offences and matters which are reviewable by the Competition Tribunal. The following, among others, are matters reviewable by the Competition Tribunal: abuse of dominant position; refusal to deal; tied selling; exclusive dealing; market restriction; and mergers. The most important of these dealing with (non-merger) business practices is the provision on the abuse of dominant position. The Competition Tribunal has provided important guidance on the interpretation of this section. See Canada (Director of Investigation and Research) v. Laidlaw Waste Systems Ldd. (1991), 37 C.P.R. (3d) 430 (C.T.). See also Canada (Director of Investigation and Research) v. NutraSweet Co. (1990), 32 C.P.R. (3d) 1 (C.T.). A commentary on these and other provisions is contained in two speeches given by Howard I. Wetston. Director of Investigation and Research, Bureau of Competition Policy: "Decisions and Developments: Competition Law and Policy," Canadian Institute, Toronto, June 8, 1992; and "Recent Developments in Competition Law: The Perspective of the Bureau of Competition Policy." Law Society of Upper Canada, Toronto, April 26, 1991. 
recognizes that compliance with the Act can best be achieved when business people have a sound understanding of the provisions of the Act. The Bureau attempts to achieve this objective by publishing information bulletins, annual reports, press releases and background material on specific cases. In addition, the Bureau officials take every opportunity to speak with lawyers, business people and others concerned with the application of the Competition Act. ${ }^{6}$ As explained in the following passages, the Bureau also provides advice on proposed business practices or plans.

The Bureau believes that corporate education is a very effective method of reducing the instances of anti-competitive activity. In view of the significant monetary penalties under the Act and the willingness of courts to hold corporations liable for the actions of employee who are relatively low in corporate hierarchy, business is increasingly placing more emphasis on corporate compliance programs. ${ }^{7}$

\section{B. IMMUNITY}

In conjunction with the Attorney General, the Bureau is examining the increased use of incentives for corporations and individuals to voluntarily report their participation in conspiracy or bid-rigging activities before such conduct comes to the Bureau's attention. Under certain circumstances, the Director may be prepared to recommend to the Attorney General that the party be granted immunity from prosecution. Given the covert nature of these offences, they are often difficult to discover or prove without the co-operation of persons who are themselves implicated in the commission of these offences. This initiative by the Bureau is just one of its more general efforts aimed at ensuring effective, fair and timely resolution of investigations arising under the Act. ${ }^{8}$

Given the respective roles of the Director and the Attorney General in enforcing the Competition Act, it should be stressed that only the Attorney General can grant immunity from prosecution under the Act. Nonetheless, the Director's recommendations have historically received careful and serious consideration by the Attorney General.

For an outline of this approach see Canada, Director of Investigation and Research, Competition Act, Information Bulletin No. 3, "Program of Compliance" June, 1989 at 4. This Bulletin and other published material, including copies of speeches, are available on request from Resource Centre, Bureau of Competition Policy, 5 Victoria St., Hull, Québec, KIA OC9 (819) 994-0798.

7. In $R$. v. Shell Products Ltd. (1990), 63 Man. R. (2d) 1 (C.A.), which involved charges under section 61 (price maintenance), the Court of Appeal rejected Shell's argument that a marketing representative who contacted a local dealer was too junior in the company's hierarchy to be a directing mind of Shell. The Court reasoned that the conviction did not rest on the marketing representative's conduct alone. It upheld the conviction of Shell on the basis of inferential evidence that he was following directions from above. It doubled the fine imposed on Shell from $\$ 100,000$ to $\$ 200,000$ after considering the profits Shell earned and the significance of the offence and concluding that a fine of $\$ 100,000$ was merely "a slap on the wrist."

8. Some general criteria for recommending immunity are set out in the Director's speech to the Canadian Corporate Counsel Association, Calgary, August 19, 1991 at 4-5. See also his speech at the Canadian Institute conference, supra note 2. 


\section{ADVISORY OPINIONS}

Under the Director's Program of Compliance, the Bureau provides advisory opinions to those who wish to avoid coming into conflict with the Act. Under this program, the Director invites company officials, lawyers and others to request opinions on whether the implementation of a proposed business plan or practice would cause an inquiry under the Act to be initiated.

These opinions consider previous jurisprudence, previous opinions and the stated policies of the Bureau. Those who seek opinions are not bound by the opinions given and remain free to adopt the plan or practice on the understanding that it may be tested before the Competition Tribunal or the Courts. The Director cannot bind himself or his successors to any opinions given. Advisory opinions are given in relation to a specific set of facts; should the details of the plan or the surrounding facts change, the matter could be subject to further examination.

In order to provide an informed opinion, the Director requires adequate disclosure of material facts relating to the plan. Obviously the more complete and accurate the information provided, the less qualified the opinion would be and the less likely the matter would be subject to further examination. Many firms in the oil and gas industry have taken advantage of this program and have been given opinions on such matters as the formation of an export cartel, the exchange of price forecasts and agreement on uniform industry standards and others. ${ }^{9}$

\section{PRIVATE ACTION}

In situations where the Director has not initiated action, firms or individuals may still be vulnerable to litigation under the Act. Section 36 of the Act provides for a private right of civil action. Anyone who has suffered losses or damages may sue those they believe to be engaged in anti-competitive behaviour. This remedy is available if one of the criminal provisions of the Act has been violated or if there has been a failure to comply with an order of the Competition Tribunal or the court. ${ }^{10}$

\section{CRIMINAL OFFENCES - HORIZONTAL AGREEMENTS}

The Competition Act contains several provisions which treat certain anti-competitive behaviour as criminal offences. In terms of allocating its resources, however, the Bureau gives top priority to offences in relation to anti-competitive agreements among competitors, known as horizontal agreements. This behaviour results in lower output, higher prices and reduced incentives for innovation and efficiency. These provisions are: section 45 dealing with conspiracy, section 47 dealing with bid-rigging and, in certain circumstances, section 61 dealing with price maintenance.

9. Some of these opinions are discussed later in the paper.

10. The constitutionality of s. 36 was confirmed by the Supreme Court of Canada in 1989. See General Motors of Canada Ldd. v. City National Leasing, [1989] 1 S.C.R. 641, 58 D.L.R. (4th) 255. See also Quebec Ready Mix Inc. v. Rocois Construction, [1989] 1 S.C.R. 698, 60 D.L.R. (4th) 124. 


\section{A. SECTION 45 - CONSPIRACY}

The conspiracy provision is the cornerstone of the Act. It reflects Parliament's view that collusive arrangements are serious criminal offences, evidenced by the lengthy prison terms and significant fines provided for in the Act. The prohibition against horizontal agreements to fix prices, allocate markets and restrict entry of competitors has been the core of Canadian competition policy since 1889. Since 1986, both corporations and individuals who are guilty of violations may receive fines of up to ten million dollars. In addition, individuals may be sentenced to jail terms of up to five years.

The Supreme Court of Canada's unanimous decision in $R$. v. Nova Scotia Pharmaceutical Society" released July 9, 1992, upheld the constitutionality of the conspiracy provision. This decision clearly settles the uncertainty about the validity of the law and is a strong affirmation of the conspiracy provision and of competition law in general. The decision also provides considerable guidance as to what type of agreements will be considered to lessen competition "unduly."

The Court recognized that two elements must be considered together to assist in determining whether there has been undue lessening of competition: the existence of some degree of market power on the part of the parties, and the existence of behaviour likely to injure competition. The Court defines market power as the ability to behave relatively independently of the market. No particular market power threshold is determinative and many factors such as barriers to entry may be considered. The Court distinguishes market power required under conspiracy law which is the ability of a firm to behave relatively independently of the market, from the market power required under the abuse of dominant position section of the Act which is substantial or complete control of a business.

Regarding injurious behaviour to competition, the Court relates this element to the nature of the agreement and the dimension of competition affected such as price, quality, service or other matters. Behaviour is also stated to encompass issues such as the object of the agreement, the manner in which it is or will be carried out, and any other conduct that may tend to reduce competition or limit entry. ${ }^{12}$

The Court emphasized that it is the combination of market power and injurious behaviour that causes an undue lessening of competition. The two elements, however, do not have to exist in equal proportions. The Court provides the examples of price fixing and market sharing agreements as examples of injurious conduct that may lessen competition unduly even if the parties' market power was not considerable. ${ }^{13}$

With regard to the fault element required by the section, the Supreme Court also stated that it would be a logical inference to draw that a reasonable business person, who can

13. Ibid. at $54-56$. 
be presumed to be familiar with the business in which he or she engages, would or should have known that the likely effect of an agreement between competitors would be to unduly lessen competition. ${ }^{14}$

\section{B. SECTION 47 - BID-RIGGING}

Bid-rigging is an agreement between parties whereby one or more bidders will refrain from submitting bids in response to a call for tenders, or bids are submitted which have been arranged between the parties. If either situation is known to the person calling tenders, no offence occurs under this section. Bid-rigging is a per se offence in that no lessening of competition need be demonstrated. Parties engaged in bid-rigging are liable to a fine at the discretion of the court, or to imprisonment for up to five years, or both. ${ }^{15}$

\section{SECTION 61 - PRICE MAINTENANCE}

Price maintenance is an attempt by suppliers to influence prices upward, or to discourage price reductions by agreement, threat, promise or like means. It is also illegal to refuse to supply a product or to discriminate against any other person because of their low pricing policy. Likewise it is illegal to attempt to induce a supplier to engage in price maintenance. There is considerable jurisprudence on section $61 .^{16}$ Those found guilty of price maintenance are liable to fines in the discretion of the Court, or imprisonment for a term not exceeding five years, or both.

Several prosecutions under section 61 have been undertaken involving infractions in downstream petroleum markets. ${ }^{17}$

\section{PENALTIES}

The Bureau's policy is to seek maximum fines in those cases involving horizontal agreements and to charge individuals where appropriate. The trend toward imposing more severe penalties for illegal cartel activities has been followed in Canada and in several other countries including the United States, Germany and Japan. ${ }^{18}$

The most recent convictions under s. 47 (bid-rigging) occurred in the flour milling case where the firms were fined a total of \$3.4 million. See Annual Report of the Director of Investigation and Research, Competition Act, for Year Ended March 31, 1991 (Hull: Consumer and Corporate Affairs Canada) at 14.

16.

See for example, Stanley Wong. "The Law of Price Maintenance in Canada: Review and Assessment" in R.S. Khemani and W.T. Stanbury, eds., Canadian Competition Policy at the Centenary (Halifax: Institute for Research on Public Policy, 1991).

17. Petroleum firms were found guilty of price maintenance in the following cases: $R$. v. Sunoco Inc. (1988), 28 C.P.R. (3d.) 287 (Ont. C.A.); R. v. Imperial Oil Lid., Ont. Co. Ct., 4 April 1984, Trotter J. (unreported); and Shell, supra note 7. In R. v. Ultramar Canada, Ont. Court (Gen.Div.), 91-7282 \& 7283, 30 May 1991, McPhee J. (unreponted), the accused firms pleaded guilty. In $R$. v. Pioneer Petroleum Ont. Court (Gen. Div.), 20 December 1991, Zura J. (unreported), the accused firm was acquitted. 
In referring a case to the Attorney General for prosecution, the Director will not hesitate to recommend that charges be laid against individuals if the evidence so warrants to act as a deterrent to others. Some of the factors considered by the Director in determining if charges should be laid against an individual are: the individual's position in the organization; his role in initiating; implementing or enforcing the conduct in question; and his knowledge of the illegality of the conduct. ${ }^{19}$

A recent example of this approach is the fines sought against five major suppliers of compressed gas and against four senior executives of these firms. The firms were fined a total of $\$ 6$ million while three of the corporate officers were fined $\$ 75,000$ each and the fourth was fined $\$ 50,000 .^{20}$

\section{GUIDANCE ON OIL AND GAS ISSUES}

\section{A. STATUTORY DEFENCES AND EXCEPTIONS}

Not all agreements between competitors violate the conspiracy provision of the Act. The Act contains twelve specific defences to conspiracies and among these the following likely have application to the oil and gas industry:

i) the exchange of statistics, subsection $45(3)(a)$;

ii) the defining of product standards, subsection 45(3)(b);

iii) measures to protect the environment, subsection 45(3)(i);

iv) the export of products, subsection 45(5); and

v) specialization agreements, sections 85 and 86 .

These defences, however, are not absolute and can be lost if the conduct affects competition in the Canadian market. The specific exceptions to the statutory defences are described in subsections 45(4) and 45(6) of the Act. Some recent advisory opinions on the export defence and the exchange of statistics defence are provided later in the paper.

The definition of bid-rigging contained in section 47 of the Act provides that no offence has occurred if the agreement or arrangement is made known to the person calling for tenders. An exception to bid-rigging is also provided in subsection 47(3) when companies are affiliates of one another.

Ibid. at 3.

30. Canadian Oxygen Limited was fined $\$ 700,000$, Union Carbide Canada Limited, Canadian Liquid Air Lid. and Liquid Carbonic Inc. were each fined \$1.7 million and Air Products Canada Ltd. was fined $\$ 200,000$. A recent fine against an individual in a misleading advertising prosecution is also of note. In January, 1992, the Alberta Court of Queen's Bench imposed the largest fine against an individual when it fined the former President of Principal Group, Donald Cormie $\$ 500,000$. See $R$. v. Cormie. Alta. Q.B., 9103-0977-C4, 22 January 1992, Dea J. (unreported). 
Subsection 61(10) of the Act provides several defences to charges of price maintenance. These defences can be used when the accused believes on reasonable grounds that the other person was engaged in the practice of:

- selling the product as a "loss-leader";

- selling the goods not for profit but to attract customers;

- misleading advertising respecting the product supplied; and

- not providing the level of servicing that purchasers reasonably expect from the other person.

\section{The Export Defence}

The Competition Act recognizes the importance of exports to the Canadian economy in its purpose clause and by providing an export defence to the general conspiracy provisions. Subsection 45(5) of the Act provides a defence to a conspiracy where the agreement in question relates only to the export of products from Canada. This defence is not absolute and can be lost under certain circumstances.

In 1991, the Bureau provided an advisory opinion to a group of companies which had proposed establishing a joint marketing organization to engage in the export sale of sulphur. Members of the proposed organization would account for 85 per cent of Canada's sulphur shipments. Individual members would be free to sell any part of their production to the North American market. Membership would be open to any person, including brokers, having Canadian-produced sulphur available for the export market. The Bureau concerns regarding this proposal were whether independent brokers in Canada would be able to continue to obtain adequate supplies of sulphur for the export markets, given the large percentage of that production by the member firms and whether the supply of sulphur from Canada to the offshore market would be reduced.

After the Bureau conducted a thorough review of the matter, including interviews with the stakeholders affected, it concluded that the proposal would not unduly lessen competition in the supply of the product to the Canadian market or reduce the real value of exports of sulphur from Canada to the offshore market. With respect to the domestic market, the Bureau determined that there would continue to be vigorous competition from producers and independent brokers. Concerning the export of sulphur from Canada to the offshore market, the Bureau determined that the real value of sulphur exports to this market would not be reduced and Canadian independent brokers would have access to product from other world producers.

\section{Exchange of Statistics}

Subsection 45(3)(a) of the Act provides defence to conspiracy if the agreement relates only to the exchange of statistics. In 1991, the Bureau provided an advisory opinion to an association of firms in the petroleum industry. They had proposed the publication of 
a survey which would show the association's members' product price forecasts and the methods used in forecasting these prices. Survey information from participants would be on a confidential basis, and under no circumstance would raw data provided by any single respondent be made public.

The Bureau advised the firms that the published survey would not in itself provide the Director with belief on reasonable grounds that a violation of section 45 had occurred. The Bureau, however, cautioned that the published survey would increase the potential for price signalling and, thus, could be a vehicle for an agreement to raise prices of certain products.

\section{Rationalization}

The rationalization of functions in the oil and gas industry are a feature of today's environment of declining energy prices. Two such areas involve the rationalization of accounting functions relating to joint ventures and the rationalization of gas processing plants.

Consideration by industry is being given to establishing a central accounting processing centre to process all basic financial and volumetric transactions relating to joint venture projects.

Such a proposal seems unlikely to cause a problem under the Act; however, the specifics of how it would be set up and operated would have to be carefully reviewed by the Director. The Director would be particularly concerned if this proposal led to companies exchanging or sharing competitively sensitive information.

The Bureau has also been advised of a plan to rationalize processing plants in the gas sector. In assessing this proposal the Bureau will consider the following issues: ${ }^{21}$

- Generally, will the plan increase the market power of the participants, for example their ability to raise prices with little constraint from other suppliers?

- Will independent producers' access to plants be affected?

- Will the plan result in increased costs for independent producers in the processing of their product?

- Will there be a reduction in the supply of product which will increase prices?

- What criteria will be used to determine which plants will be closed?

21. The decision of the Supreme Court in Nova Scotia Pharmaceutical Society, supra note 11 at 49-57, provides very useful general guidance as to the content of an inquiry under the conspiracy provisions. 


\section{Information Exchanges}

Like many other industries, members of the oil and gas sector often participate in industry meetings or trade associations where information is exchanged. These information exchanges may, however, breach the conspiracy provision of the Competition Act. To determine whether or not information exchanged among industry participants may breach the conspiracy provision, the Bureau would consider the following factors:

- The nature of the information exchanged. The Bureau would be concerned if the information exchanged related to sensitive areas such as a firm's marketing strategies or its methods of determining its prices.

- The size of the geographic market affected. The Bureau would consider the scope of the market affected by the information exchange, whether it be local, provincial, national or North American.

- The market structure in which association members operate. Of particular concern would be whether the industry is one which is highly concentrated and subject to high barriers to entry.

- The particular conduct of the association in the dissemination of information to its members. The Bureau's concern in this regard is whether the association has engaged in policing activities including the imposition of penalties and sanctions on its members to achieve an anti-competitive goal.

The following are suggestions to avoid coming into conflict with the Competition Act when information is exchanged among industry members:

- Information exchanges should be of a generalized nature and non-company specific.

- Individual firms should be free to determine which policies to follow on their own.

- Information should be based on past historical data. There should be no indication of future prices or trading terms.

- Associations should exercise extreme caution in the formulation and implementation of guidelines in relation to important competitive aspects of their business.

- Where there is collection of data from industry participants (market share, pricing etc.), it should be collected by an independent firm, and the collection of this data should ensure that the anonymity of members is preserved. 
- The results from the data collected should be publicly available. The prospect of a wider audience, be they non-members or the general public, will reduce the likelihood of anti-competitive effects.

- Associations should avoid any policing to coerce members to follow association guidelines.

- No sanctions should be imposed on members who choose not to follow association guidelines.

\section{Regulated Conduct Defence}

The regulated conduct defence is a doctrine that has developed in the jurisprudence as a result of a series of cases which challenged the application of Canada's competition laws to specific conduct. ${ }^{22}$ Simply stated, some activities which meet the elements of a provision of the Competition Act are permissible because the conduct in question is undertaken pursuant to valid regulatory legislation. The regulated conduct defence is limited to specific conduct permissible by valid legislation and should not be taken as a defence to all types of behaviour in an industry. In other words, while certain conduct may be removed from the ambit of the Competition Act, the industry is not. Whether or not such a defence may be applicable depends on a careful examination of the nature of the legislation in the particular case under review. ${ }^{23}$

In 1982, the Supreme Court of Canada in Jabour ${ }^{24}$ applied the regulated conduct defence to the disciplinary action taken by a self-governing profession functioning under a constitutionally valid provincial statute, and held that it was not subject to the criminal provisions of the Combines Investigations Act. This case concerned the issue of whether the B.C. Law Society could penalize lawyers for advertising. The Court ruled that if a legislature has the jurisdiction to regulate a particular matter, then it is also within its jurisdiction to decide upon the form of regulation, which in that case was self-regulation.

Reference re Farm Products Marketing Act (1957), 1 S.C.R. 198, 7 D.L.R. (2d) 257; R. v. Canadian Breweries, [1960] O.R. 601, 126 C.C.C. 133 (H.C.).

3. For additional analysis on the regulated conduct defence see two speeches by Calvin S. Goldman, former Director of Investigation and Research: "The Competition Act and the Professions," Canadian Bar Association, Toronto, April 25, 1989; and "The Competition Act as It Relates to the Regulated Sector," Canadian Association Members of Public Utility Tribunals, Saskatoon, September 10, 1986. Canada (Attorney General) v. Law Society of British Columbia, [1982] 2 S.C.R. 307, [1982] 5 W.W.R. 289. 
Recent decisions such as B.C. Fruit Growers, ${ }^{25}$ Waterloo Law Association, ${ }^{26}$ Industrial Milk, ${ }^{27}$ Air Canada ${ }^{28}$ and Mortimer ${ }^{29}$ have stated that the activity in question must be specifically authorized in the legislation for the regulated conduct defence to apply.

As a result of this jurisprudence, the Bureau believes that the following elements must exist before the regulated conduct will likely be accepted by a court:

- The relevant legislation must be validly enacted.

- The activity in question must not only fall within the scope of the relevant legislation, but it must also be specifically authorized.

- The authority of the regulatory body must have been exercised.

- The activity or conduct in question has not frustrated the exercise of authority by the regulatory body.

\section{B. NATURAL GAS PRICING ISSUES}

In 1990, the Bureau provided an advisory opinion concerning the process to be followed in negotiating a natural gas sales contract between six natural gas producers, an aggregator and a local distribution company (LDC). Two specific areas of concern were raised. First, whether it is permissible for the aggregator to hold meetings with the six producers to discuss pricing strategy. Secondly, whether it would be permissible for two representatives from the six producers to participate directly in the negotiations with the LDC. The Bureau examined this matter under the price maintenance, bid-rigging and conspiracy provisions.

The Bureau determined that the price maintenance provision did not apply to this situation. There was little opportunity for the six producers to influence the price of natural gas upward given the large number of buyers and sellers of natural gas in Canada. The members of the group were in effect price takers who sell their product at or about the price determined by the market. Also, since there was a large number of transactions in the market it was likely that any price negotiated would be directly influenced by the price of other similar transactions.

25. R. v. British Columbia Fruit Growers Ass'n (1985), 11 C.P.R. (3d) 183 (B.C.S.C.).

26. Waterloo Law Ass'n v. Canada (Attomey General) (1986), 58 O.R. (2d) 275, 35 D.L.R. (4th) 751 (H.C.).

27. Industrial Milk Producer Ass'n v. British Columbia (Milk Board) (1988), 18 F.T.R. 147, 21 C.P.R. (3d) 33.

28. R. v. Air Canada, Ont. Prov. Ct., 25 March 1986, Porter J. (unreported).

29. Mortimer v. Corp. of Land Surveyors (British Columbia) (1989), 35 B.C.L.R. (2d) 394, 25 C.P.R. (3d) 233 (S.C.). 
With respect to bid-rigging, the Bureau determined that since the LDC was made aware that the six producers were permitting a joint tender, the bid-rigging provision did not apply.

Finally, with respect to conspiracy, the Bureau determined that since the six producers only represented a very small portion of the industry supply and accounted for a small portion of the LDC's supply, there would not likely be an undue lessening of competition and hence there was no breach of section 45 .

\section{ALBERTA'S NATURAL GAS MARKETING ACT}

In response to the pricing concerns of natural gas producers after deregulation of the oil and gas industry in 1985, Alberta enacted the Natural Gas Marketing Act ("NGMA"). ${ }^{30}$ The NGMA, in part, responds to producers' concerns regarding the determination of the price components in netback-priced gas contracts. Under these contracts, producers sell gas to aggregators on a netback basis, meaning the price paid to the producer is determined by the resale price downstream.

Aggregators or shippers purchase gas from several producers. This gas is then pooled and is sold by the aggregators to various purchasers. Part Two of the NGMA establishes a mechanism which provides producers with some influence over the prices at which aggregators resell gas. Section 9 of the NGMA prohibits a shipper (aggregator) of netback gas from either removing gas from Alberta for resale to another person or from delivering that gas in Alberta for resale to another person, unless there has been a finding of producer support.

The prescribed procedures in determining a finding of producer support include a system of voting by ballots. This requires the aggregator to solicit ballots from all producers on whether each producer approves or disapproves of the price at which the aggregator proposes to purchase its natural gas supplies, or the mechanism which it proposes to use to determine that price. The question on the ballot must be in a form that requires a "Yes" or "No" answer only. ${ }^{31}$ Aggregators often convene information sessions prior to the ballots being mailed to producers to inform producers of their marketing efforts and to persuade them to support the contracts obtained.

The dynamics of the natural gas industry are such that producers, who supply gas to aggregators, are also often competitors of the aggregators. Thus, each party should be circumspect about its conduct in the information sessions. The Bureau would be particularly concerned if producers agreed not to compete with the aggregator in certain markets. Alberta's Natural Gas Marketing Act clearly does not authorize such anticompetitive agreements between an aggregator and producers. The regulated conduct defence would not, therefore, be applicable to such an agreement and the parties to the agreement would be subject to the general conspiracy provisions of the Competition Act. 
The Bureau would also be concerned if, for example, at the information session, the aggregator indicated that better prices could be obtained if the producers curtailed the quantity of gas available to a specific market and encouraged producers to reduce their supply of gas. Such an attempt by an aggregator to influence prices upward could contravene the price maintenance provisions of the Competition Act. The NGMA does not permit this behaviour and consequently, the related conduct defence again would not be applicable.

Another concern regarding these information sessions is whether sensitive market information such as pricing strategies is exchanged. Such an exchange of information is not authorized by the NGMA and would, therefore, be subject to the general conspiracy provisions of the Competition Act.

In 1991, the marketing operations of the British Columbia Petroleum Corporation were transferred from a Crown Corporation to a private company owned and controlled by British Columbia natural gas producers, called Canwest Supply (1989) Limited. British Columbia has similar legislation to Alberta's Natural Gas Marketing Act governing the removal of natural gas from the province. ${ }^{32}$ The Director's concerns regarding the conduct of producers and aggregators would, therefore, be similar to the concerns indicated above, namely that producers and the aggregators not discuss and exchange pricing information, or enter into anti-competitive arrangements.

\section{CONCLUSION}

Vigorous competition in the oil and gas industry is essential to the health of Canada's economy. Not only does it promote greater economic welfare, it also strengthens firms' ability to meet the challenges of an increasingly competitive international marketplace. An effective and well understood competition law makes a vital contribution to this goal.

The Bureau will continue its efforts to clarify both the meaning and boundaries of the provisions of the Act and its enforcement policies. Jurisprudence and guidelines will help explain the rules of the marketplace to industry members and enable them to effectively compete in the domestic and global marketplace.

The record fines that have recently been imposed on both corporations and on individuals should serve notice to those contemplating collusion that such behaviour is taken very seriously by the courts.

Competition law issues relating to the activities of firms in the oil and gas industry are often intricate and complicated. As such, lawyers and business-people should take advantage of the Bureau's program of Advisory Opinions when proposals that may raise Competition Act issues are contemplated. 